Original Research Article

\title{
An experimental evaluation of gastro protective activity of paracetamol on ulcerogenicity of some NSAIDs in albino rats
}

\author{
Rajashekar Y. R. ${ }^{1 *}$, Shobha S. N. ${ }^{2}$
}

\begin{abstract}
${ }^{1}$ Department of Pharmacology,
${ }^{2}$ Department of Pathology, Adichunchanagiri Institute of Medical Sciences, BG Nagar, Mandya, Karnataka, India
\end{abstract}

Received: 23 February 2017 Accepted: 27 February 2017

\section{*Correspondence to: \\ Dr. Rajashekar Y. R., \\ Email: \\ rajashekar.yr@gmail.com}

Copyright: () the author(s), publisher and licensee Medip Academy. This is an openaccess article distributed under the terms of the Creative Commons Attribution NonCommercial License, which permits unrestricted noncommercial use, distribution, and reproduction in any medium, provided the original work is properly cited.

\begin{abstract}
Background: Fixed dose combinations (FDCs) of NSAIDs are commonly prescribed and extensively sold over the counter. An indiscriminate usage of them leads to toxicity, mainly involving gastrointestinal system. Paracetamol appears to have controversial reputation regarding its gastro protective action. In this background, the study was planned to evaluate gastro protective effect of paracetamol on the ulcerogenicity of some relatively new NSAIDs in their therapeutic and sub therapeutic doses.

Methods: Gatric toxicity and gastric juice analysis- Pyloric ligation method was adopted for assessing the ulcer index of 3 NSAIDs namely aceclofenac, nimesulide and lornoxicam individually and in combination with paracetamol. Gastric juice collected was subjected for total juice volume, free acidity, combined acidity and total acid output.

Results: Paracetamol produced non significant gastric damage similar to that of control. When co administered with therapeutic doses of aceclofenac, nimesulide and lornoxicam, there was significant decrease in their gastric toxicity in a uniform manner and the ulcerogenicity of these NSAIDs in sub therapeutic doses was not affected by paracetamol. This upholds the uniform gastro protective activity of paracetamol in this study and this could be explained by its anti acid secretory action on gastric juice.

Conclusions: Paracetamol, itself has least gastric damaging property. When co administered with other NSAIDs, their toxicity is rather reduced than enhancing the mucosal damage by them. Thus FDCs of various NSAIDs available in market are partially justifiable.
\end{abstract}

Keywords: FDC, Gastroprotection, NSAIDs, Paracetamol, Ulcer index

\section{INTRODUCTION}

Fixed dose combination (FDC) of various No steroidal anti-inflammatory drugs (NSAIDs) with paracetamol are the most commonly used drugs for alleviating the painful symtoms of many and most clinical disorders. They are also extensively sold over the counter drugs worldwide. They are effective in providing symptomatic relief, but their indiscriminate usage either as prescriptional or non prescriptional drugs, poses significant risk to increased mortality and morbidity requiring hospitalization across the globe. ${ }^{1,2}$ Their toxicity profile mainly affects gastrointestinal system, though other systems like liver, kidney, heart, lungs and skin are not spared.
The majority of the gastrointestinal side effects could be mild like bloating, cramping, pain, acid reflux, diarrhea or constipation. The more serious gastrointestinal adverse effects such as gastric erosions, ulcers, perforations and bleeding are often life threatening. These toxic effects are the direct consequences of their mechanism that is also responsible for their therapeutic efficacy and appears to be an inherent risk with all NSAIDs, though it may vary from one drug to another. Studies indicate that aspirin has relatively higher toxicity than diclofenac and ibuprofen while paracetamol has least toxicity. NSAID users are found to have approximately 3 times greater risk than non users for developing gastrointestinal damage. ${ }^{3}$ Several attempts such as, co-administration of misoprostol, proton pump inhibitors, $\mathrm{H}_{2}$ blockers and paracetamol have been made to reduce the gastrointestinal toxicity of 
NSAIDs without compromising their efficacy. Studies indicate that paracetamol when administered concomitantly with various gastric irritants like absolute alcohol, inorganic acids and alkalies, reduces their gastric toxicity. ${ }^{4}$ The minimal gastric toxicity of paracetamol and its protective role is said to be due to increase in prostaglandins production in gastric mucosa. ${ }^{4,5}$

However, this gasto protective property of paracetamol appears to be not uniform with different NSAIDs and moreover there are controversial reports regarding gastro protective propertyof paracetamol with some NSAIDs. Gastric toxicity of aspirin, indomethacin and ibuprofen was deceased, when co administered with paracetamol in rats, but that of phenylbutazone and glafenine was not altered. ${ }^{4,6}$ Paracetamol showed gastro protective activity with aspirin and ethanol in humans in one study, while in another study paracetamol showed no such protection with aspirin, and ibuprofen. ${ }^{7-9}$ Yet another experimental study showed enhanced gastric toxicity of ibuprofen, when co administered with paracetamol, contrary to its protective role. $^{10}$

Literature survey shows that there is paucity of information regarding ulcerogenecity of aceclofenac, nimesulide and lornoxicam, when administered with paracetamol. These controversial reports about gastro protective activity of paracetamol and paucity of similar information about other relatively newer NSAIDs prompted our present study.

Aims and objectives of the study were to evaluate fixed dose combinations of NSAIDs viz. paracetamol with aceclofenac, paracetamol with nimesulide and paracetamol with lornoxicam, with regard to ulcerogenic activity and to study the interaction of paracetamol with relatively newer NSAIDs viz. aceclofenac, nimesulide and lornoxicam in their sub therapeutic equivalent doses on gastric ulcerogenicity.

\section{METHODS}

Healthy adult albino rats with normal activity and behavior, weighing between 150-250gms were obtained central animal house of the institution. While selecting animals randomly, care was taken to exclude diseased, pregnant and previously experimented ones. They were divided into control and different treatment groups, each having 6 animals. They were housed in separate individual cages with free supply of standard pellet diet and tap water ad libitum and they were experimented under standard laboratory conditions with 12 hours alternate dark and light cycles. They were acclimatized to lab conditions one week prior to experiment period.

\section{Drugs}

- Paracetamol $135 \mathrm{mg} / \mathrm{kg}$ bw per oral administration

- Aceclofenac 25 and $5 \mathrm{mg} / \mathrm{kg}$ bw per oral administration
- Nimesulide 25 and $5 \mathrm{mg} / \mathrm{kg}$ bw per oral administration

- Lornoxicam 2 and $0.2 \mathrm{mg} / \mathrm{kg}$ bw per oral administration

These drugs were obtained from pharma labs in pure powder form of I.P. grade. Rat equivalents to human therapeutic doses were calculated with the help of converting table described elsewhere ${ }^{11}$ and sub therapeutic equivalent doses were discovered by carrying out a series of experiments on inflammatory models and it is the dose at which no anti-inflammatory activity was seen.

\section{Gastric toxicity studies}

Each animal group was treated per orally with respective drug or drug combination for 10 days. On day 11, under thiopentone sodium anaesthesia, overnight fasted animals were fixed on OT table. The anterior abdominal was opened, pylorus of the stomach was taken out and ligated. ${ }^{12}$ The stomach was replaced back into abdomen and abdominal wall was sutured. The animals were withdrawn from food and water during post operative period. After 4 hours, the animals scarified with over dose of thiopentone sodium anaesthesia.

From these sacrificed animals, stomach was dissected out, cut opened along the greater curvature and contents were collected into tubes for estimating the volume, free acidity and total acidity. The gastric mucosa was with normal saline and examined with the help of magnifying lens for gastric lesions.

An arbitrary scoring system as described by Gupta MB et al, was followed to determine the gastric toxicity. Scores were given depending on the lesions found on gastric mucosa. $^{13}$

- 10- Denuded epithelium

- 20-Petechial and frank haemorrhage

- 30- One or two ulcers

- 40-Multiple ulcers

- 50- Perforated ulcers

The severity of gastric ulceration was expressed in terms of ulcer index. The mean ulcer index of each treatment group was calculated and compared with that of control.

\section{Estimation of free acidity and total acidity of gastric juice}

Determined by titration method as described by Parmer et al, 1984. ${ }^{14}$ The gastric content collected was subjected for centrifugation (3000 RPM for $10 \mathrm{~min}$ ). Later supernatant of gastric content of each animal was individually assayed for the volume of gastric secretion, free acidity by titration to $\mathrm{pH} 3.5$ with $0.01 \mathrm{~N} \mathrm{NaOH}$ using Topfer's reagent indicator and total acidity by titration to $\mathrm{pH} 8.0$ with $0.02 \mathrm{~N} \mathrm{NaOH}$ using phenolpthaleine indicator. Free 
acidity and total acidity were expressed in micro equivalents $/ 4 \mathrm{hr}$. Mean value of treatment groups were calculated and compared with that of control.

\section{RESULTS}

All obtained test result parameters of the present study were appropriately tabulated, mean with standard errors were calculated and statistically analyzed by ANOVA followed by Dunnet's test and students ' $\mathrm{T}$ ' test. The level of significance was calculated at 0.05 level.

In gastric toxicity studies, aceclofenac, nimesulide and lornoxicam, in their therapeutic doses showed significantly higher ulcer index and paracetamol showed ulcer index similar to control group.

Table 1: Effect of various drug treatments on gastric secretion (sub anti-inflammatory doses).

\begin{tabular}{|c|c|c|c|c|c|c|c|c|c|}
\hline No. & $\begin{array}{l}\text { Drug treatment } \\
\text { dose }(\mathrm{mg} / \mathrm{kg})\end{array}$ & $\begin{array}{l}\text { Ulcer index } \\
\text { Mean } \pm \text { S.E.M }\end{array}$ & $\begin{array}{l}\text { Score } \\
0\end{array}$ & $\begin{array}{l}\text { Score } \\
10\end{array}$ & $\begin{array}{l}\text { Score } \\
20\end{array}$ & $\begin{array}{l}\text { Score } \\
30\end{array}$ & $\begin{array}{l}\text { Score } \\
40\end{array}$ & $\begin{array}{l}\text { Score } \\
50\end{array}$ & $\begin{array}{l}\mathbf{P} \\
\text { value }\end{array}$ \\
\hline 1 & Control (1\% Gum acacia) & 13. $33 \pm 6.16$ & $50.00 \%$ & - & $16.66 \%$ & $33.33 \%$ & & - & \\
\hline 2 & $\begin{array}{l}\text { Paracetamol (135) } \\
+ \text { Aceclofenac (5) }\end{array}$ & $20.00 \pm 5.77$ & $16.66 \%$ & $16.66 \%$ & $33.33 \%$ & $16.66 \%$ & $16.66 \%$ & - & NS \\
\hline 3 & $\begin{array}{l}\text { Paracetamol (135)+ } \\
\text { Nimesulide (5) }\end{array}$ & $25.00 \pm 4.28$ & - & $16.66 \%$ & $33.33 \%$ & $33.33 \%$ & $16.66 \%$ & - & NS \\
\hline 4 & $\begin{array}{l}\text { Paracetamol (135)+ } \\
\text { Lornoxicam }(0.2)\end{array}$ & $28.33 \pm 3.07$ & - & - & $33.33 \%$ & $50.00 \%$ & $16.66 \%$ & - & NS \\
\hline & F-Value & 1.03 & & & & & & & \\
\hline
\end{tabular}

Table 2: Effect of various drug treatments on gastric ulcerations.

\begin{tabular}{|c|c|c|c|c|c|c|c|c|}
\hline No. & $\begin{array}{l}\text { Drug treatment } \\
\text { dose }(\mathrm{mg} / \mathrm{kg})\end{array}$ & $\begin{array}{l}\text { Ulcer index } \\
\text { Mean } \pm \text { S.E.M }\end{array}$ & $\begin{array}{l}\text { Score } \\
0\end{array}$ & $\begin{array}{l}\text { Score } \\
10\end{array}$ & $\begin{array}{l}\text { Score } \\
20\end{array}$ & $\begin{array}{l}\text { Score } \\
30\end{array}$ & $\begin{array}{l}\text { Score } \\
40\end{array}$ & $\begin{array}{l}\text { Score } \\
50\end{array}$ \\
\hline 1 & Control (1\% Gum acacia) & $13.33 \pm 6.16$ & $50.00 \%$ & & $16.66 \%$ & $33.33 \%$ & - & - \\
\hline 2 & Aceclofenac (25) & $41.66 \pm 1.67 * *$ & & & - & - & $83.33 \%$ & $16.66 \%$ \\
\hline 3 & Nimesulide (25) & $40.00 \pm 0.00 * *$ & & & - & - & $100 \%$ & - \\
\hline 4 & Loraxicam (2) & $43.33 \pm 2.10 * *$ & & & - & - & $66.66 \%$ & $33.33 \%$ \\
\hline 5 & Paracetamol (135) & $15.00 \pm 5.64$ & $33.33 \%$ & $16.66 \%$ & $16.66 \%$ & $33.33 \%$ & - & - \\
\hline 6 & $\begin{array}{l}\text { Paracetamol (135) } \\
+ \text { Aceclofenac (25) }\end{array}$ & $35.00 \pm 2.24 *$ & & & - & $50.00 \%$ & - & - \\
\hline 7 & $\begin{array}{l}\text { Paracetamol (135)+ } \\
\text { Nimesulide (25) }\end{array}$ & $33.33 \pm 2.11 *$ & & & - & $66.66 \%$ & $33.33 \%$ & - \\
\hline 8 & $\begin{array}{l}\text { Paracetamol (135)+ } \\
\text { Lornoxicam (2) }\end{array}$ & $38.33 \pm 2.29 * *$ & & & - & $33.33 \%$ & $50.00 \%$ & $16.66 \%$ \\
\hline & F-Value & 16.27 & & & & & & \\
\hline
\end{tabular}

$\mathrm{n}=6$, Anova $\mathrm{F}_{7,40}$ at $\mathrm{p}=0.05-2.25$ Dunnet's Test* $\mathrm{p}<0.05 * * \mathrm{p}<0.01$

$\mathrm{P}=0.01-3.12$

Table 3: Effect of various drug treatments on gastric secretion.

\begin{tabular}{|c|c|c|c|c|}
\hline $\begin{array}{l}\text { Drug treatment } \\
\text { dose }(\mathrm{mg} / \mathrm{kg})\end{array}$ & $\begin{array}{l}\text { Gastric juice } \\
\text { volume in } \mathbf{~ l} \\
(\text { Mean } \pm \text { S.E.M) }\end{array}$ & $\begin{array}{l}\text { Free acidity ( } \mu \\
\text { equivalents /4 } \\
\text { hrs) } \\
\text { Mean } \pm \text { S.E.M }\end{array}$ & $\begin{array}{l}\text { Total acidity ( } \boldsymbol{\mu} \\
\text { equivalents } / 4 \\
\text { hrs) } \\
\text { Mean } \pm \text { S.E.M }\end{array}$ & $\begin{array}{l}\text { Total acid output } \\
\text { ( } \mu \text { equivalents } / 4 \\
\text { hrs) Mean } \pm \text { S.E.M }\end{array}$ \\
\hline Control (1\% Gum acacia) & $3.80 \pm 0.18$ & $5.10 \pm 0.19$ & $8.81 \pm 0.32$ & $33.64 \pm 2.45$ \\
\hline Aceclofenac (25) & $5.00 \pm 0.26^{*}$ & $5.71 \pm 0.19$ & $9.35 \pm 0.36$ & $46.76 \pm 3.61 *$ \\
\hline Nimesulide (25) & $5.41 \pm 0.37 * *$ & $5.88 \pm 0.24 *$ & $10.03 \pm 0.49$ & $44.93 \pm 3.40 *$ \\
\hline Loraxicam (2) & $5.18 \pm 0.23 *$ & $6.01 \pm 0.29 *$ & $10.41 \pm 0.61 *$ & $53.50 \pm 2.21 * *$ \\
\hline Paracetamol (135) & $4.13 \pm 0.18$ & $5.11 \pm 0.13$ & $8.81 \pm 0.29$ & $36.31 \pm 1.57$ \\
\hline Paracetamol (135)+Aceclofenac (25) & $4.60 \pm 0.38$ & $5.93 \pm 0.29$ & $9.75 \pm 0.46$ & $44.53 \pm 3.59$ \\
\hline Paracetamol (135)+ Nimesulide (25) & $4.46 \pm 0.24$ & $5.73 \pm 0.22$ & $9.65 \pm 0.43$ & $43.15 \pm 3.06$ \\
\hline Paracetamol (135)+ Lornoxicam (2) & $4.50 \pm 0.35$ & $5.80 \pm 0.22 *$ & $9.68 \pm 0.25$ & $43.37 \pm 3.17$ \\
\hline F-Value & 4.79 & 3.82 & 1.17 & 5.78 \\
\hline
\end{tabular}

$\mathrm{n}=6$, Anova $\mathrm{F}_{7,40}$ at $\mathrm{p}=0.05-2.25$ Dunnet's Test* $\mathrm{p}<0.05 * * \mathrm{p}<0.01$

$\mathrm{P}=0.01-3.12$ 
Table 4: Effect of various drug treatments on gastric secretion.

\begin{tabular}{|c|c|c|c|c|}
\hline $\begin{array}{l}\text { Drug treatment } \\
\text { dose (mg/kg) }\end{array}$ & $\begin{array}{l}\text { Gastric juice } \\
\text { volume in } \mathrm{ml} \\
(\text { Mean } \pm \text { S.E.M) }\end{array}$ & $\begin{array}{l}\text { Free acidity ( } \mu \\
\text { equivalents } / 4 \\
\text { hrs) Mean } \pm \text { S.E.M }\end{array}$ & $\begin{array}{l}\text { Total acidity ( } \mu \\
\text { equivalents } / 4 \\
\text { hrs) Mean } \pm \text { S.E.M }\end{array}$ & $\begin{array}{l}\text { Total acid output } \\
\text { ( } \mu \text { equivalents } / 4 \\
\text { hrs) Mean } \pm \text { S.E.M }\end{array}$ \\
\hline Control (1\% Gum acacia) & $3.80 \pm 0.18$ & $5.10 \pm 0.19$ & $8.81 \pm 0.32$ & $33.64 \pm 2.45$ \\
\hline Paracetamol (135)+Aceclofenac (5) & $4.30 \pm 0.16$ & $5.22 \pm 0.08$ & $8.0 \pm 0.16$ & $35.50 \pm 2.50$ \\
\hline Paracetamol (135)+ Nimesulide (5) & $4.0 \pm 0.24$ & $5.41 \pm 0.16$ & $9.02 \pm 0.18$ & $37.20 \pm 1.6$ \\
\hline Paracetamol (135+ Lornoxicam (0.2) & $4.35 \pm 0.31$ & $5.53 \pm 0.21$ & $9.25 \pm 0.13$ & $38.60 \pm 1.8$ \\
\hline F-Value & 1.22 & 1.68 & 1.32 & 1.17 \\
\hline
\end{tabular}

$\mathrm{n}=6$, Anova $\mathrm{F}_{3,20}$ at $\mathrm{p}=0.05-3.10$ Dunnet's Test $\mathrm{p}=\mathrm{NS}$

$\mathrm{P}=0.01-3.12$

Coadministration of paracetamol in different treatment groups, also produced significant higher ulcer index, however this value is significantly less $(\mathrm{p}<0.05$ to 0.01$)$ than individual treatment group, suggesting gastroprotection role of paracetamol. Paracetamol with sub therapeutic doses of NSAIDs, also produced ulcer index similar to that of control.

In gastric secretion studies also, individual NSAIDs significantly increased gastric juice volume, free acidity, total acidity and total acid output. Paracetamol co administration significantly decreased all these parameters.

\section{DISCUSSION}

As already described, the main objective of the study was to evaluate the interaction of different NSAIDs like aceclofinac, Nimesulide and lornoxicam in their therapeutic and subtherapeutic equivalent doses with paracetamol in rats.

Controversial reports about gastro protective effect of paracetamol prompted the present study. Though there are no much reports regarding gastro protective effect of paracetamol when co administered with aceclofenac, Nimesulide and lornoxicam, there are several reports regarding such an activity of paracetamol when co administered with other agents like ethanol, inorganic acids and alkalies and indomethacin, aspirin. ${ }^{4,15}$ In contrast to these earlier reports, the other studies have shown that paracetamol when coadministered failed to reduce the gastric toxicity of ethanol, aspirin, ibuprofen, phenylbutazone and glafenine in rats. ${ }^{4,8,16,17}$ These could be attributed to higher doses used (3900mg and $2600 \mathrm{mg}$ ) and shorter duration of treatment compared to that of present study. Similarly in earlier study enhanced gastric toxicity of ibuprofen, when co administered with paracetamol could be due to low dose $(25 \mathrm{mg} / \mathrm{kgbw})$ of paracetamol and shorter duration (5days) of treatment. ${ }^{12}$

Paracetamol when co administered with subtherapeutic doses of aceclofenac or Nimesulide or lornoxicam, there was no significant increase in gastric toxicity as compared to that of control, indicating that paracetamol does provide protection against gastric toxicity to this agents when used in lower doses.

Except paracetamol, individual NSAID treatment groups significantly increased the gastric juice secretion, free acidity and total acid output. Only lornoxicam significantly increased total acid levels. These findings partly agree with earlier reports of aspirin and indomethacin with respect to gastric juice and total acid output. $^{8,18}$ Whereas paracetamol group and its combination with aceclofenac or nimesulide or lornoxicam, in their therapeutic as well as in subtherapeutic doses did not show any significant increase in the gastric juice volume, free acidity and total acid output. And there are no similar studies in the past involving these three NSAIDs.

Paracetamol, when co administered with these NSAIDs apparently exhibits gastroprotection protection activity by lowering volume free acidity and total acid output of gastric juice. Although it is difficult to explain the variable gastro protective mechanism of paracetamol, it can be explained based on earlier reports. It acts by stimulating mucosal prostaglandins, by increasing mucus secretion, by increasing alkaline secretion or by masking the mucosal cells. ${ }^{5}$

There are many fixed dose combination (FDC) of NSAID having paracetamol in common are available in the market are extensively consumed. Rationale for such combination is not clearly defined and moreover such FDCs are not approved by WHO. The findings of the present study, if could be extrapolated to clinical situation, clearly exclude the claimed advantages of such drug combinations. The study recommends conducting further studies to explore FDCs interaction on inflammatory models.

\section{CONCLUSION}

An addition of paracetomol to therapeutic equivalent doses of all the three aceclofenac, nimesulide, lornoxicam significantly reduced the gastric toxicity as compared to that of the individual treatment of these NSAIDs by decreasing free acidity and total acid output and thus the 
ulcer index. Even though there are controversial reports regarding the gastro protective activity of paracetamol, here the study clearly shows no such variability with all the three studied NSAIDs and thus their FDCs with paracetamol is partly justifiable.

Funding: No funding sources Conflict of interest: None declared

Ethical approval: The study was approved by the Institutional Ethics Committee

\section{REFERENCES}

1. Tramer MR. Quantative estimation or rare adverse events which follow a biological progression: A new model applied to chronic NSAID use. Pain. 2000;85:169-82.

2. Tamblyn R. Unnecessary prescribing of NSAIDs and the management of NSAID related gastropathy in medical practice. Ann. Intern Med. 1997;127:429-38.

3. Gabriel SE, Jaakkimainen L, Bomardier C. Risks for serious gastrointestinal complications realed to use of non steroidal anti-inflammatory drugs. Ann Intern Med. 1991;115:787-96.

4. Von Kolfchoten AA. Protection by paracetamol against various gastric irritants in the rat. Toxicol. App Pharmacol. 1987;69:37-42.

5. Konturek SJ. Role of epidermal growth factor in healing of chronic gastroduodenal ulcers in rats. Gastroenterology. 1988;94:1300-07.

6. Konturek SJ. Prevention of etanol and aspirin induced gastric mucosal lesions by paracetamol and salicylate in rats: role of endogenous prostaglandins. Gut. 1982;23:536-40.

7. Stern AI. Protective effect of acetaminophen against aspirin and etanol induced damage to the human gastric mucosa. Gastroenyerology. 1984;86:728-33.

8. Graham DY. Non steroidal anti-inflammatory effect of sulindac sulfoxide and sulfide on gastric mucosa. Clin Pharmacol. Ther. 1985;38:65-70.
9. Lanza FL. Effect of acetaminophen on human gastric mucosal injury caused by ibuprofen. Gut. 1986;24:440-43.

10. Bhattcharya SK. Potentation of gastric toxicity of ibuprofen by paracetamol in the rat. J Pharm. Pharmacol. 2002;43:520-21.

11. Ghosh MN. Fundamentals of experimental pharmacology, Calcutta: Scientific book agency. Calcutta. 1984;230:148-53.

12. Sibai BM. Prevention of preeclampsia with low dose aspirin in healthy nulliparious pregnant women. $\mathrm{N}$ Eng J Med. 1993;329:1213-18.

13. Bhowmick S. Antinuclear activity of N-phthaloyl GABA-A new GABA mimetic agent. Ind J Exp. Bio. 1990;28:190-92.

14. Rao CHV, Airam KS, Goel RK. Experimental evaluation of Bocopa monniera on Rat gastric ulceration and secretion. Ind. J. Physiol and Pharmacol. 2000;44:335-41.

15. Steel RW. Oral antipyretic therapy: Evaluation of aspirin- acetaminophen combination. Amer J Child. 1972;123:204- 07.

16. Nakagawa M, Okabe S. Lack of cyto protection y acetaminophen against ethanol- HCL. Etanol and HCL Aspirin induced gastric mucosal lesions in rats. 1984;43:469-71.

17. Lanza FL, Royer GL, Nelson RS. Endoscopic evaluation of the effects of aspirin, buffered aspirin and enteric coated aspirin on gastric and duodenal mucosa. Engl. J. Med. 1994;303:136-38.

18. Feldman M, Colutri TJ. Effect of Indomethacin on gastric acid and bicarbonate secretion in humans. Gastroenterology. 1984;87:1339-43.

Cite this article as: Rajashekar YR, Shobha SN. An experimental evaluation of gastro protective activity of paracetamol on ulcerogenicity of some NSAIDs in albino rats. Int J Basic Clin Pharmacol 2017;6:774-8. 